ANUARIo DE Estudios MEdiEvales (AEM)

$36 / 2$, julio-diciembre de 2006

pp. 687-712

ISSN 0066-5061

\title{
EL ASOCIACIONISMO POPULAR URBANO \\ EN LA SEGUNDA MITAD DEL SIGLO XV. EL PROCURADOR DEL PUEBLO DE ORIHUELA EN $1459-1460^{1}$
}

\author{
JUAN ANTONIO BARRIO BARRIO \\ Universidad de Alicante
}

Resumen: En la ciudad de Orihuela entre 1459 y 1460 se produjo un movimiento de protesta popular que pretendía reformar en profundidad las instituciones municipales en lo referente a su sistema electoral, fiscalidad, gestión de los recursos públicos y alcanzar un mecanismo de crédito popular a bajo interés. Los protagonistas de este fenómeno fueron miembros de la mano menor, en su mayor parte artesanos vinculados al sector textil. La estrategia utilizada por su líder, el pelaire Joan Rodríguez, fue la del discurso político para atraerse partidarios y la solicitud de procuraciones notariales a su favor. Con ellas se constituyó en procurador del pueblo y como tal presentó propuestas de reformas ante el rey y ante el municipio. A pesar de ser encarcelado y procesado fue apoyado por la monarquía, recibiendo de Juan II el cargo de Baile local de la ciudad de Orihuela.

Palabras clave:Asociación Popular; Procurador Pueblo; Artesanos Textil; Reformas; Crédito; Revuelta.

\begin{abstract}
Between 1459 and 1460, the town of Orihuela was the centre of a popular protest movement aimed at radically reforming the municipal institutions as regards the electoral system, management of public resources and the creation a system of low interest loans. The leaders of the movement were manual workers, mostly creaftsmen from the textile sector. Their leader, the wool carder Joan Rodríguez, used political discourse to attract supporters and obtain proxy votes. With these, he became the judicial attorney of the town and then presented the King and the municipal authorities with proposals for political and social reforms. Despite being imprisoned and tried, he was supported by the monarchy and was named baile (royal rent collector) for the town of Orihuela by king Juan II.
\end{abstract}

Keywords: Popular Association; Judicial Attorney; Town Craftsmen Textiles; Wool Carders; Reforms; Loan; Revolt.

\section{SUMARIO}

1. El asociacionismo medieval. 2. Los pelaires y el procurador del pueblo en la primera mitad del siglo XV. 3. La propuesta de reformas populares. 4. La confesión de Joan Rodríguez. 5. El proceso y la construcción de la memoria histórica. 6. A modo de conclusión.

${ }^{1}$ El presente artículo se ha realizado en el marco del proyecto de investigación "Poder público, sociedad y cultura en el Reino de Valencia, ss. XIII-XV"(VIGROB2005071). 


\section{EL ASOCIACIONISMO MEDIEVAL}

El asociacionismo, fue una de las novedades y uno de los fenómenos más característicos de la Edad Media, ya que pervivía la necesidad de reunirse en asociaciones por parte de los individuos, para la mejor defensa de sus propias personas y de sus intereses, ante la ausencia o la dificultad del Estado para asegurar a sus ciudadanos estas necesidades básicas. Fue, a juicio de Pini, la respuesta natural de la sociedad medieval ante un Estado que se manifestaba impotente y la descomposición del poder feudal, junto a la necesidad cotidiana de buscar amparo y ayuda que no siempre se obtenía de aquellos que detentaban o ejercían el poder. El asociacionismo es un fenómeno propio y peculiar de la Edad Media, ya que fue en este tiempo histórico, cuando por razones políticas o religiosas, el individuo no tenía reconocida una existencia singular e individual, y adquiría dicho reconocimiento cuando formaba parte de un clan familiar o de una colectividad definida, es decir de una asociación ${ }^{2}$. En esta línea para Bonassie las corporaciones socio-profesionales, se convertían en instrumentos de control económico en manos de la autoridad municipal ${ }^{3}$. Desde los concejos municipales se aprobaron ordenanzas tendentes a proteger los intereses de la clase dominante. De esta forma, las asociaciones socio-profesionales actúan como eficaces mecanismos de encuadramiento fiscal y político de los artesanos, lo que propiciaba que la monarquía y los municipios fomentasen el asociacionismo profesional entre la población urbana. Como afirma Riera Melis ningún oficio ha conseguido organizarse corporativamente de forma espontánea, sin interferencia de los poderes públicos ${ }^{4}$. Representando estas corporaciones profesionales una de los fenómenos más característicos de la historia urbana medieval ${ }^{5}$.

Dentro del mundo del artesanado y del trabajo urbano, conocemos dos tipos de asociaciones que proliferaron en las ciudades europeas, especialmente en los siglos finales del medievo. Me refiero a las cofradías religiosas y a las corporaciones socio-profesionales, que son las que han sido estudiadas con mayor detalle y profundidad.

Estas corporaciones profesionales representan uno de los aspectos más característicos de la historia urbana medieval ${ }^{6}$. Las corporaciones de oficio eran, por tanto, las asociaciones de artesanos habitualmente de un mismo ramo de producción, creadas para la defensa de sus intereses económicos y

\footnotetext{
${ }^{2}$ A.I. PINI, L'associazionismo: una peculiarietà e un' eredità del Medioevo, M. MEDICA, "Haec Sunt Statuta. Le corporazione medievali nelle miniature Bolognesi", Modena, 1999, p. 9. ${ }^{3} \mathrm{P}$. BONNASSIE, La organización del trabajo en Barcelona a fines del siglo XV. Barcelona,
1975, p. 139.

${ }^{4}$ A. RIERA I MELIS, La aparición de las corporaciones de oficio en Cataluña (1200-1350), "Cofradías, gremios, solidaridades en la Europa Medieval. XIX Semana de Estudios Medievales". Estella' 92. Pamplona, 1993, p. 317.

${ }^{5}$ A.I. PINI, L'associazionismo: una pecularietà, p. 13.

${ }^{6}$ Ibídem.
} 
laborales. Organizaciones que contaban con el reconocimiento público y una mínima organización formal ${ }^{7}$. Los principales aspectos que definieron las ordenanzas o reglamentos aprobados por las corporaciones fueron tres, la regulación del trabajo y de las normas de fabricación, el control de las materias primas y de las medidas de coerción ejercidas por los veedores designados por cada oficio ${ }^{8}$. La constitución de la corporación, con la aprobación de sus reglamentos y ordenanzas, convertía a esta asociación de trabajadores, en una institución en toda regla, convertida en persona moral y jurídica y con una autonomía "plena" sancionada por un estatuto de derecho público 9 . Hemos subrayado "plena", ya que en este caso discrepamos de dicha afirmación. Frente a la autonomía plena de la que disfrutaba el municipio como Universitas ${ }^{10}$, las corporaciones de oficio constituidas como tales en la Corona de Aragón, veían mermada considerablemente diversas esferas de su autonomía política.

Constituir, Corpus et Universitas, supone varias consecuencias para la comunidad beneficiaria. La primera y principal es que se puede reunir de manera licita, sin autorización previa de su Señor, para consulere et deliberare. Este derecho de libre reunión para deliberar es el fundamento básico de la existencia de toda Communitas y condiciona verdaderamente su organización institucional. Esto explica que todas las comunidades que aspiran a la autonomía se esfuerzan en primer lugar por hacer reconocer su derecho a reunirse, congregare y de deliberar, consulare o tener Consulado. Rigaudere afirma la existencia de todo un vocabulario, que traduce una evidente voluntad de conseguir franquicias a través del poder de decisión que se reconoce a toda comunidad que dispone de esta doble capacidad de reunión y de deliberación, libertad indispensable a toda actividad administrativa y política ${ }^{11}$.

En el Reino de Valencia las corporaciones de artesanos no disponían de dichas atribuciones, propias de la Universitas. Era la Curia de la Gobernación la que podía conceder dichos permisos de reunión. La serie documental Manaments i empares del Archivo del Reino de Valencia, recoge abundante documentación sobre los permisos de reunión otorgados por el Gobernador a las diferentes corporaciones artesanales. A través de las noticias que han sido publicadas sobre cerca de trescientos documentos que afectan a permisos de reunión de artesanos, se observa la importancia jurídica, política y simbólica que tenía el derecho de reunión. Las licencias otorgadas por la

${ }^{7}$ J.M M Monsalvo ANTÓN, La debilidad política y corporativa del artesanado en las ciudades castellanas de la Meseta (primeros pasos, siglos XIII-med. XIV), S. CASTILLO (ed.), El trabajo a través de la Historia ("Actas del II Congreso de la Asociación de Historia Social"), Madrid, 1996, p. 101.

${ }^{8} \mathrm{D}$. MENJOT, Murcie Castillane. Una ville au temps de la frontière (1243-milieu du XV siècle ), I, Madrid, 2002, pp. 438-446.

${ }^{9} \mathrm{~B}$. CHEVALIER, Corporations, conflits politiques et paix sociale en France aux XIV et $X V^{e}$ siècles, "Revue Historique", 543 (1982), p. 18.

${ }^{10} \mathrm{~J}$.A. BARRIO BARRIO, La introducción del término Universitas en las instituciones municipales del Reino de Valencia, "Actas do IV Congreso Internaciomal de Latim Medieval Hispânico", Lisboa, 12-15 de Outubro de 2005, Lisboa, 2006, pp. 191-201.

${ }^{11}$ A. Rigaudière, Gouverner la Ville au Moyen Âge, París, 1993, p. 31. 
Curia de la Gobernación presentan de forma estándar los siguientes datos, la fecha de solicitud del permiso de reunión, el oficial que concede la licencia, los solicitantes, la fecha y en ocasiones la hora de la reunión, el lugar de reunión, la causa de la asamblea y el oficial que para la salvaguarda del interés público podía estar presente en la reunión ${ }^{12}$. La propia existencia y consolidación de las corporaciones artesanales no fue bien vista por la Corona, que ejerció a través del Gobernador un férreo control sobre las mismas a través de dos mecanismos, la supervisión de los estatutos confeccionados y la intervención en sus reuniones ${ }^{13}$. La presión ejercida por la Corona sobre las reuniones de las Cofradías, que tenían un carácter religioso y asistencial, también aparecía en sus ordenanzas ${ }^{14}$. A pesar de todo existía una clara diferencia en la consideración que tenía la Corona a la hora de regular el permiso de reuniones de las Corporaciones de oficios, que estaban sometidas al control del Gobernador y las Cofradías religiosas que tenían en sus estatutos la concesión del permiso para celebrar una serie de capítulos ${ }^{15}$, reuniones al año, que venían determinadas en su número y en las fechas de celebración de las mismas. La libertad que disfrutaban los cofrades de numerosas cofradías para reunirse sin la presencia de oficiales reales a no ser que los propios cofrades lo solicitaran, al igual que el hecho de no necesitar licencia alguna para reunirse en capítulo ${ }^{16}$, es también un contraste con la rigidez normativa que afectaba a las corporaciones de oficios en su libertad de reunión y en la restricción que les obligaba a hablar en sus asambleas exclusivamente de sus asuntos internos. Precisamente esta coerción significaba el objetivo final de las medidas restrictivas de la Corona hacia las corporaciones gremiales, limitando de esta forma la potestad normativa de las corporaciones en la redacción de sus estatutos ${ }^{17}$.

El objeto de mi estudio es indagar en un tipo de asociacionismo poco conocido $^{18}$. Se trata de la asociación puntual de ciudadanos utilizando la vía de la procuración legal para designar entre ellos a un, síndico, dirigente o líder reconocido legalmente como tal y con el objetivo de presentar en nombre de todo el colectivo una serie de propuestas con carácter reformista ante las autoridades pertinentes, monarquía y municipio. Este colectivo o asociación no responde, por tanto, a las características de una corporación socioprofesional, una cofradía religiosa e incluso de lo que podríamos conocer y

${ }^{12} \mathrm{~J}$. CASTILLO; L.P. MARTÍNEZ, Els gremis medievals en les fonts oficials. El fons de la Governaçio del regne de València en temps d'Alfons el Magnànim (1417-1458). Valencia, 999, p. 15

${ }^{13}$ Ibídem, p. 29.

${ }^{14} \mathrm{M}$. BENÍTEZ BOLORINOS, Las cofradías medievales en el Reino de Valencia (1329-1458), Alicante, 1998, p. 88.

${ }^{15}$ El capítulo era el acto principal de la Cofradía y consistía en la reunión de todos los cofrades. M. BENÍTEZ BOLORINOS, Las cofradías medievales, p. 82.

${ }^{16}$ Ibídem, p. 88.

${ }^{17}$ J. CASTILlO; L.P. MARTíneZ, Els gremis medievals en les fonts oficials, pp. 30-31.

${ }^{18}$ Salvo los excelentes trabajos realizados por Carme Batlle para Barcelona. 
fue definido por Jacques Heers como partido político ${ }^{19}$. Se ajusta más a la definición expresada por Chevalier, como un enfrentamiento confuso, en torno al poder, más que un fenómeno de lucha de clases y que no provocó una transformación tangible de la estructura social. Considera este autor que la autentica renovación social y económica en el mundo del trabajo fue la puesta en funcionamiento del régimen corporativo ${ }^{20}$. Creo que esta aseveración esconde una de las claves del análisis cenital sobre el mundo del trabajo en el siglo XV. Conviene recordar que en paralelo a fenómenos oficiales y legales de aprobación de reglamentaciones y ordenanzas laborales, de corporaciones socio-profesionales, de cofradías religiosas, etc, se producían movimientos artesanos de protesta, se elevaban quejas, y se planteaban propuestas de reformas, al margen de los cauces habituales que había ido definiendo el poder. Hay que considerar siguiendo con el lucido planteamiento del historiador galo, que las primeras actuaciones no sólo fructificaron, sino que además sentaron las bases de las relaciones laborales durante todo el periodo pre-industrial, mientras que los movimientos considerados sociales, reformistas, de protesta, etc., no dejaron ninguna huella profunda, pudiendo, por tanto, insertarlos en el contexto de las luchas políticas puntuales que se libraban en cada ciudad y en momentos históricos precisos en cada una de ellas. Cuando en este tipo de movimientos se producen coincidencias en el tiempo y en espacios socio-políticos similares, ello nos debe llevar a pensar en los elementos comunes a dichos movimientos, para intentar encontrar una primera explicación y respuesta razonable para explicarlos todos y cada uno de ellos.

En Pamplona las gentes del común rechazaron violentamente las pretensiones fiscales de la monarquía, realizando sus reuniones y juntas al margen de la legalidad ${ }^{21}$.

No es habitual encontrar para escenarios como el castellano, este tipo de manifestaciones políticas realizadas desde las bases del común o del artesanado, habiendo definido Nieto Soria para Castilla las asociaciones políticas en dos únicos contextos, el asociacionismo político de los municipios a través de la Hermandad y el asociacionismo político de los miembros de la nobleza formalizados en contratos de alianza reconocidos $o$ en confederaciones $^{22}$. Esta ausencia del artesanado o del común en el asociacionismo político de Castilla se puede explicar por la debilidad política y corporativa del artesanado castellano ${ }^{23}$.

\footnotetext{
${ }^{19} \mathrm{~J}$. HEERS, Los partidos y la vida política en el occidente medieval, Buenos Aires, 1986. Revisando todas y cada una de las definiciones, modelos y situaciones que Heers califica de partido en la Edad Media, no encontramos que sirvan para el conflicto de carácter político, social y económico que tuvo como escenario la ciudad de Orihuela en el año 1460.

${ }^{20} \mathrm{~B}$. CHEVAlier, Corporations, conflits politiques et paix sociale, p. 18.

${ }^{21}$ J.A. FERNÁNDEZ DE LARREA ROJAS, Conflicto social y represión armada. Pamplona, 1386, "Principe de Viana". Anejo 14 (1992), p. 363.

${ }^{22} \mathrm{~J}$.M. NIETO SORIA, La parole: un instrument de la lutte politique dans la Castille de la fin du Moyen Age, "Revue Historique", 306 (2004), p. 723.

${ }^{23}$ J.M a MONSALVO ANTÓN, La debilidad política y corporativa. 
Para realizar esta investigación me he centrado en un episodio desconocido sobre una asociación urbana de carácter popular, que con objetivos reformistas actúo en la ciudad de Orihuela entre 1459 y 1460, con la estrategia de elevar al rey y al municipio, diversas propuestas de reformas en la ciudad. Esta asociación estaba constituida fundamentalmente por ciudadanos de la mano menor, entre los que debía predominar el artesanado textil. Se designó como representante y dirigente de la misma a Joan Rodríguez, un conocido y reputado pelaire de la localidad, utilizando en todo momento los mecanismos jurídicos que tenían a su alcance, a través de la vía de la procuración, pero al margen de las asociaciones convencionales, corporaciones de oficios o cofradías religiosas. Joan Rodríguez logró conseguir el apoyo de la monarquía para su causa. Este tipo de alianzas, por otra parte, fueron frecuentes en las actuaciones de los artesanos frente a las oligarquías locales. Empleando la terminología de la época, la mano menor se alió con la monarquía en su competencia frente a la mano mayor. En los movimientos sociales en Francia en la segunda mitad del siglo XIV los artesanos menores se unieron al rey y a sus colectores, en una especie de "frente de clase" 24 . En cierta medida, los ciudadanos menores, en su mayor parte artesanos, se dirigen a su monarca, ante la posible desafección del grupo dirigente urbano, al que se enfrentan por no haber ejercido su rol de intermediarios entre el Estado y ellos, como sector social desamparado ${ }^{25}$. Esta alianza de los menores con la monarquía se puede constatar también en ciudades peninsulares como Barcelona ${ }^{26}$ o Cuenca ${ }^{27}$.

De este episodio de protesta artesanal en la ciudad de Orihuela, ha quedado abundante documentación en los archivos de cancillería real, en el Archivo del Reino de Valencia, y en las actas municipales del Consell de Orihuela, en el Archivo Histórico de Orihuela. A pesar de ello, este suceso ha permanecido totalmente inédito, hasta la lectura de mi tesis doctoral ${ }^{28}$.

Las únicas referencias que tradicionalmente se han dado sobre este suceso han sido totalmente distorsionadas y mostrando una imagen peyorativa del líder artesanal que encabezó este movimiento social. De Joan Rodríguez

\footnotetext{
${ }^{24}$ B. Chevalier, Corporations, conflits politiques et paix sociale en France, p. 33.

${ }^{25}$ Ibídem, p. 37.

${ }^{26}$ Sobre el particular los numerosos trabajos que Carme Batlle ha dedicado a ilustrar en Barcelona este fenómeno son un buen botón de muestra.

${ }^{27}$ En el caso de Cuenca, la rebelión nobiliaria de 1465 contra Enrique IV fue apoyada en ciudades castellanas como Cuenca por los grupos privilegiados de la ciudad que controlaban el regimiento perpetuo de la misma. Enrique IV en este contexto apoyó a los grupos inferiores de la clase social dominante, impulsando medidas como la substitución de las regidurías perpetuas por regidurías anuales, lo que beneficiaba a este grupo social que participaba del poder, pero en sus niveles inferiores. Ouedando clara la intencion del rey de apoyar a los linajes que no en sus niveles inferiores. Quedando clara la intencion del rey de apoyar a los linajes que no habían alcanzado el regimiento y que aspiraban a hacerlo y que a su vez se mantenian leales a

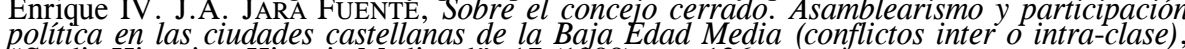
politica en las ciudades castellanas de la Baja Edad Media (conf
"Studia Historica, Historia Medieval", 17 (1999), pp. 126 ys.

${ }^{28} \mathrm{En}$ mi tesis doctoral ofrecía los primeros datos rigurosos sobre este acontecimiento, a partir de documentación inédita del Archivo del Reino de Valencia, que demostraba la conexión un municipio medieval: Orihuela, 1308-1479. Tesis doctoral, Universidad de Alicante, 1993. 
la historiografía nos ha dejado el testimonio y análisis de este personaje oriolano realizado por el cronista mosén Bellot en el siglo XVII y que ha servido de base para los posteriores estudios de Gisbert, Vilar, y tantos otros. En el cronista Bellot que ha sido la fuente para el resto de historiadores, ha primado su visión de la historia de Orihuela favorable a la memoria histórica del grupo dirigente y las fuentes utilizadas que procedían de los ricos fondos conservados en el Archivo Municipal de Orihuela que el erudito conocía perfectamente, definiendo de esta forma el pelaire "Juan Rodríguez fue un hombre sedicioso y malintencionado, porque...conmovía al pueblo, prometiéndoles muchas cosas contra el consejo y sus ordenanzas, y muchos, engañados con sus palabras, le hacían procura contra el consejo y las recibían los notarios de licencia del lugarteniente..."29. Sobre este texto, Gisbert definió a Rodríguez como un "hombre sedicioso y mal inclinado" que ya había sido acusado en Lorca de fabricar falsa moneda y condenado a muerte. Refugiado en Orihuela consiguió embaucar a varios convecinos para conseguir mejorar en los privilegios y ordenanzas de la ciudad, a tenor de lo cual estalló un motín dirigido por él. Fue detenido por el Justicia criminal a instancias de los jurados y encarcelado ${ }^{30}$. Por su parte Vilar, aunque recoge también la postura de Bellot, pretende ir más lejos aunque con el fundamento de contar sólo con la escueta información aportada por el cronista e intuye que el tal Rodríguez era un miembro más del proletariado urbano, un miserable, un mendigo o un vagabundo más de los que pululan por las calles de Orihuela y que con un "largo historial delictivo" a sus espaldas había alterado a la opinión pública con sus discursos incendiarios. Vilar destaca paradójicamente como a pesar de su oscuro historial consiguió viajar a la corte para transmitir al monarca información, que posteriormente fue denunciada como falsa y maliciosa por los munícipes. Concluye Vilar su exposición afirmando que "víctima de sus propios manejos, enredos y mentiras...terminó dando con sus huesos en la cárcel" $"$.

\section{LOS PELAIRES Y EL PROCURADOR DEL PUEBLO EN LA PRIMERA MITAD DEL SIGLO XV}

La ofensiva de los pelaires ante el Consell, para conseguir mejoras legislativas y medidas proteccionistas se inició en 1427, con una representación de los pelaires, de la que formaba parte nuestro personaje $\mathrm{j}^{32}$, que presentó ante el Consell una queja sobre la entrada de tejidos comunes originarios de Valencia, pues consideraban que les perjudicaba ya que alegaban que el oficio 454.

${ }^{29} \mathrm{P}$. Bellot, Anales de Orihuela. Ed. J. Torres Fontes, tomo I, Murcia, 2001, pág.

${ }^{30}$ E. Gisbert Ballesteros, Historia de Orihuela, III, Orihuela, 1903, p. 388.

${ }^{31} \mathrm{~J}$.B. VILAR. Historia de la ciudad de Orihuela. Los siglos XIV y XV en Orihuela, III. Murcia, 1977. pp. 82-83.

${ }^{32}$ Miquel López, Miquel Sanz, Antoni Marí, Joan Rodríguez y Pere Pérez.

ANUARIo De Estudios MEdiEvales (AEM), 36/2, julio-diciembre 2006, pp. 687-712. ISSN 0066-5061 
de la pelairía había venido a menos en Orihuela por la entrada de telas valencianas, razón por la que solicitaban al consistorio una solución para que el oficio volviera a ser lo que fue en otros tiempos ${ }^{33}$.

Uno de los más destacados pelaires de Orihuela era Joan Rodríguez, del que tenemos las primera noticias en 1427 cuando formó parte de una delegación de cinco pelaires oriolanos ante el consistorio municipal, para presentar una queja en nombre de los pelaires de Orihuela por la situación de crisis del sector, por la entrada de tejidos comunes originarios de Valencia ${ }^{34}$. En 1443 los jurados oriolanos concedieron el arrendamiento de la sisa del pan al pelaire Joan Rodríguez por valor de 122 florines, lo que suponía una cifra considerable para el nivel de vida de Orihuela ${ }^{35}$. Su trayectoria vital es un ejemplo de las posibilidades de ascenso social vinculado a los oficios textiles, al igual que en ciudades castellanas como Cuenca ${ }^{36}$.

Joan Rodríguez tuvo una importante participación en la vida política de Orihuela en el contexto de las crisis políticas que se produjeron tras la introducción de la insaculación y las dificultades de la puesta en marcha del nuevo sistema electoral. Previamente había ocupado el cargo de clavario en 1444 y en 1445 tras la introducción de la insaculación fue graduado en el saco de ciudadanos menores. En junio de 1459 Juan II suspendía la elección del sobrecequiero, que se había celebrado en Pascua por las quejas presentadas por un grupo de ciudadanos menores sobre la graduación que se había efectuado antes de la elección, al frente del cual estaba Joan Rodríguez. Los ciudadanos menores se veían discriminados en el acceso a los oficios municipales de Orihuela ${ }^{37}$. ...emperò, per ço com pretenit clamor d'En Johan Rodríguez de la dita ciutat per si e altres molts ciutadans menors de aquella pretenents-se preiudicats de la forma del dit regiment e encara de la graduació de les persones per als officis de la dita ciutat en virtut del dit regiment... ${ }^{38}$.

Realizando una tipología comparativa, podemos hablar de un grupo socio-profesional que a través de la compra del caballo armado, ha accedido al grupo dirigente en su escalafón inferior, no formando parte de los grupos privilegiados, y viendo vetado o dificultado su acceso a estos grupos superiores, lo que limitaba extraordinariamente sus posibilidad de influir activamente en las decisiones políticas. Desde esta óptica y acercandonos a modelos defendidos recientemente para los conflictos urbanos castellanos ${ }^{39}$,

\footnotetext{
${ }^{33} \mathrm{AHO}$ (Archivo Histórico de Orihuela), Contestador, $\mathrm{n}^{\mathrm{0}}$ 20, ff. 64v-65r. 1427, julio, 27.

${ }^{34} \mathrm{AHO}$, Contestador, $\mathrm{n}^{\mathrm{o}}$ 20, ff. 64v-65r. (1427, julio, 27).

${ }^{35} \mathrm{AHO}$, Contestador, $\mathrm{n}^{\mathrm{o}} 26$, ff. 84r-85r. (1443, enero, 1 y 3).

${ }^{36} \mathrm{~J}$.A. JARA FUENTE, Sobre el concejo cerrado. Asamblearismo y participación, pp. $132-133$

${ }^{37}$ ARV (Archivo del Reino de Valencia), Real, reg. 280, ff. 118v-120v. (1459, junio, 11).

${ }^{38}$ ARV, Real, reg. 280, f. 118v. (1459, junio, 11).

${ }^{39}$ J.A. JARA FUENTE, Sobre el concejo cerrado. Asamblearismo y participación. Idem, Doble representación y cruces de intereses: las contradicciones inherentes al segmento élite pechera (Castilla en el siglo XV), en I. ALFONSO, J. ESCALÓN, G. MARTín, coords.), Lucha politica. Condena y legitimación en la España medieval. Lyon, 2004, pp. 297-312.
}

ANuARIo De Estudios Medievales (AEM), 36/2, julio-diciembre 2006, pp. 687-712. ISSN 0066-5061 
se podría hablar de un conflicto intra-clase más que de una lucha inter-clases. Lo cierto es que para Orihuela y para la clase privilegiada dirigente era una oposición entre un grupo privilegiado y otro de menestrales al que consideran inferior y al que desprecian. Como en el caso de la ciudad de Cuenca ${ }^{40}$, las principales aspiraciones de los ciudadanos menores, encabezados por Joan Rodríguez, era la de compartir de una forma más directa las tareas de gobierno con las clases privilegiadas. También y como en el caso de las ciudades castellanas, en la ciudad de Orihuela desde la implantación de la normativa electoral de insaculación en 1445, se había limitado a los ciudadanos menores el acceso a los oficios de "carácter servicial", y a una mínima representación de ocho miembros en el Consell general que estaba formado por cuarenta, con lo que los treinta y dos consellers que sumaban los caballeros y los ciudadanos mayores, les facultaba para poder tomar todas las decisiones políticas sin necesidad de consensuar ninguna con los menores. Asimismo se cerraba a los ciudadanos menores el acceso al justiciazgo y a la juradería, cargos equivalentes al regimiento castellano.

Además de la actuación política del pelaire Joan Rodríguez, sólo conocemos la elección en 1449 del pelaire Daniel Rodrigo como conseller y en 1448 la del pelaire Miguel Sanz como lugarteniente del almotacén ${ }^{41}$. Miguel Sanz había formado parte junto a Joan Rodríguez de la comisión de cinco pelaires que en 1427 presentó ante el Consell una queja sobre la situación de crisis que atravesaba el sector textil pañero en Orihuela.

La representación de los menestrales en los cargos municipales de Orihuela era muy reducida, ya que a diferencia de otras localidades como Barcelona o Valencia no se recogía en las normativas electorales un cupo especifico para el artesanado. Por otra parte, la exigencia de poseer caballo armado para poder acceder a los principales cargos municipales de Orihuela, alejaba a la mayor parte de los menestrales del acceso a los oficios municipales. Las únicas menciones de participación en la política municipal durante el reinado de Alfonso $\mathrm{V}^{42}$ se centran en estos tres personajes Joan Rodríguez, Daniel Rodrigo y Miguel Sanz, que debían ocupar un lugar de preeminencia dentro de los pelaires, uno de los sectores más numerosos del artesanado oriolano, al formar parte dos de ellos de esta delegación que acudió ante el Consell en 1427.

\footnotetext{
${ }^{40} \mathrm{~J}$.A. JARA FuENTE, Sobre el concejo cerrado. Asamblearismo y participación política, p. 124 .

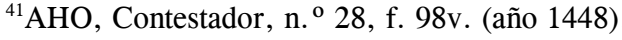

${ }^{42}$ En la elaboración de mi tesis doctoral realicé un vaciado prosopográfico de toda la documentación del reinado de Alfonso V, la serie más completa del Archivo Histórico de Orihuela, con todos los datos de los vecinos que ocuparon algún cargo público, arrendaron alguna renta municipal, tenían deudas con el municipio, etc. J.A. BARRIO BARRIO, El ejercicio del poder en un municipio medieval. 


\section{LA PROPUESTA DE REFORMAS POPULARES}

En diciembre de 1459 Joan Rodríguez presentó ante el Consell General de la ciudad una solicitud de reformas municipales, que iba a tener como principal consecuencia su encarcelamiento poco después. En su memorándum se presentaba ante el consistorio como ... axi com a hun hom singular del poble de la dita ciutat e com a procurador de aquell... La denominación principal con la que se definía Joan Rodríguez, como procurador del pueblo, coincide con términos similares utilizados en otras ciudades de la Corona de Aragón como Barcelona, donde la Busca, se denominaba como l'estament popular ${ }^{43}$, el sindicato de los tres estamentos y pueblo ${ }^{44}$.

Una posible influencia en la acción emprendida y en la estrategia de Joan Rodríguez, podía venir de la aportación de la predicación realizada en Orihuela durante la primera mitad del siglo XV. Es conocido el papel desempeñado por la elocuencia y el uso de la palabra en las luchas políticas y sociales de los siglos bajomedievales ${ }^{45}$. Las germanías de Valencia tuvieron en la predicación del prior del monasterio de los Predicadores de Valencia la espoleta para que arrancará el movimiento popular ${ }^{46}$.

La situación eclesiástica de Orihuela generaba un caldo de cultivo propició a la ebullición y a los discursos incendiarios de algunos predicadores. El pleito secular que mantenía la villa de Orihuela con la diócesis de Cartagena-Murcia con el fin de conseguir la segregación eclesiástica de dicha diócesis y alcanzar la erección de un obispado propio, había llegado a momentos de gran tensión en la primera mitad del siglo XV. La situación de la cristiandad occidental inmersa en un cisma, con la vía conciliar propugnada en Basilea, amén de la política internacional de la Corona de Castilla y la Corona de Aragón, facilitaron la efímera concesión de un Obispado propio para Orihuela en1442, cuyo titular iba a ser Pere Roiç de Corella, hijo del Gobernador Ximén Pérez de Corella ${ }^{47}$. Fruto de estas tensiones la ciudad de Orihuela estuvo condenada habitualmente a entredicho. En este clima de crispación política y eclesiástica y en el contexto previo y posterior al proceso de Joan Rodríguez, hemos localizado dos documentos de gran valor. El primero de ellos, sin datar, pero dado que aparece citado Ximén Pérez de Corella, debe ser ubicado en el contexto de la concesión del obispado, es una

${ }^{43}$ C. BATLLE, La crisis social y económica de Barcelona a mediados del siglo XV. Barcelona, 1973, I, p. 192.

${ }^{44}$ C. BATLLE, El Sindicato del pueblo de Barcelona en 1454, "VI Congreso de Historia de la Corona de Aragón", Madrid, 1959, pp. 291-303.

${ }^{45}$ J.M. NIETO SORIA La parole: un instrument de la lutte politique; E. ARTIFONI, Sullieloquenza politica nel Ducento italiano, "Quaderni Medievali" 35 (1993), pp. 57-78; C.
IANNELLA, Giordano da Pisa: etica urbana e forma della societă. Pisa, 1999.

${ }^{46}$ V.J. VAllÉs BORRÁs, La Germanía, Valencia, 2000, pp. 20-21.

${ }^{47}$ Vid. A. CARRASCO RoDRÍGUEZ, La ciudad de Orihuela y el pleito del Obispado en la Edad Moderna. Tesis de Doctorado. Universidad de Alicante, 2001. 
carta enviada por Jaume Rocamora ${ }^{48}$, mensajero de Orihuela en Valencia, a las autoridades de Orihuela sobre las conversaciones, consejos y noticias que ha recibido en Valencia. De todo el texto, lo más interesante es la alusión a un fraile que predicaba en la plaza diciendo que los pueblos se debían revolver contra los oficiales (... aquex frare que preyca en la plaça dient que los pobles se devien avolotar contra los oficials... $)^{49}$.

La denuncia y propuesta de reformas de Joan Rodríguez fue presentada por escrito y leída en el Consell municipal del día 21 de diciembre, inmediatamente después de celebrarse la elección de justicias. Este hecho evidencia que no se le había permitido formular sus demandas personalmente ante las autoridades municipales y que el hecho de leer la suplicación que había presentado en una fecha tan señalada, era motivo de honda preocupación para los munícipes oriolanos.

La base de su denuncia se centraba en que el Consell había comprado censales y estaba muy endeudado y que dichos censales se cargaban a 2 sueldos por libra (10\%). Esta actuación era perjudicial para la comunidad de la ciudad y por tanto para su sacra majestad (con estos términos se refería al soberano Juan II). Es interesante que el alegato de Rodríguez recoja esta apelación jacobina a la "comunidad" contra la elite ${ }^{50}$. El término comunidad también fue utilizado por los agermanados valencianos para aludir a su movimiento ${ }^{51}$

Proponía para paliar esta situación, comprar censales a razón de veinte mil o veinticinco mil por mil y anunciaba que había personas dispuestas a prestar dinero a dicho interés (4\%-5\%). Solicitaba por ello licencia y poder del Consell para poder negociar y comprar dichos censales en nombre del Consell. También denunciaba la existencia de muchos logreros en la ciudad y la práctica pública de la usura, lo que consideraba era en gran ignominia de nuestro señor Díos y de su sacra majestad y en gran daño a la ciudad y comunidad. Solicitaba al Consell dar orden a los corredores de oreja para revisar los libros de todos los usureros ${ }^{52}$. El Consell otorgó poder al justicia criminal y a los jurados para que examinaran dicha suplicación y preparasen la respuesta pertinente, todo ello en nombre del Consell, al servicio de la majestad del señor rey y en beneficio y reposo de la cosa publica de la ciudad. Las autoridades municipales en primera instancia mantenían las formas y en

\footnotetext{
${ }^{48}$ Jaume Rocamora, era un destacado miembro de la oligarquía oriolana. Desempeñó relevantes puestos al servicio del municipio como mensajero y diputado en cortes. Su actividad como mensajero esta documentada desde 1426. Sus principales cometidos fueron el de mensajero en la ciudad de Valencia, ante el rey, síndico en las cortes de Monzón convocadas en 1435 y diputado de la Generalitat Valenciana. En el momento de las negociaciones para conseguir del concilio de Basilea la erección del obispado de Orihuela, actuaba como mensajero de Orihuela en la ciudad de Valencia y diputado por la ciudad de Orihuela en la Generalitat.

${ }^{49}$ AHO, Contestador, D-1, f. 141r. (sin fecha).

${ }^{50} \mathrm{C}$. Astarita, Del feudalismo al capitalismo. Cambio social y político en Castilla y Europa Occidental, 1250-1520, Valencia-Granada, 2005, p. 17.

${ }^{51}$ V.J. VALLÉS BORRÀs, La Germanía, p. 16.

${ }^{52} \mathrm{AHO}$, Contestador, no 31 , f. 9 r-v. (1459, diciembre, 21).
} 
su primera respuesta igualaban la solemnidad y devoción pública mostrada por el demandante.

Uno de los problemas habituales de los artesanos, era el endeudamiento que contraían con el maestro, y cuya liquidación condicionaba todo cambio de empleo ${ }^{53}$. En Florencia uno de los motivos de las luchas de las artes menores contra los miembros de las artes mayores, era la anulación o la congelación de las deudas que los artesanos tenían contraídas con los mercaderes-banqueros ${ }^{54}$. Esta relación capitalista que se desarrolló en las ciudades europeas, tenía una de sus manifestaciones en el hecho de que el maestro artesano perdía por endeudamiento la propiedad de sus medios de producción que pasaban al empresario-mercader ${ }^{55}$. En los siglos finales de la Edad Media, el endeudamiento se acrecentó de manera considerable, con prestamos al consumo o prestamos a la producción ${ }^{56}$. Aunque este tipo de deuda podía afectar a todos los sectores sociales, los artesanos se podían ver gravados severamente por un tipo de préstamo usurario a un interés muy elevado. Esta situación repercutía en los artesanos, en la inversión en sus talleres, en beneficio del pañero o mercader-empresario, que veía facilitada sus posibilidades de controlar los medios de producción de estos artesanos textiles. Asimismo y desde las instancias de poder municipal se apoyaban las medidas de tipo corporativo, como la aprobación de los reglamentos de las corporaciones de oficios. El régimen corporativo impedía que el beneficio pudiera reinvertise en la producción ${ }^{57}$.

Desde el siglo XIV el censal como forma de deuda pública fue una prática utilizada habitualmente por las instituciones municipales del reino de Valencia. La contratación de prestamos por los municipios valencianos a través de cambistas, permitía a los miembros de los patriciados urbanos prestar tranquilamente dinero al municipio, ocultando su identidad tras el parapeto del cambista, que ocultaba la identidad de estos prestamistas conscientemente en la mayoría de los casos, evitando que las actas municipales reflejasen sus nombres ${ }^{58}$. La forma práctica que tenía un Consell municipal para conseguir un préstamo en forma de censal, era recurrir a los corredores, que a cambio de un porcentaje en la operación, presentaban ofertas concretas y comunicaban al municipio a qué interés podrían conseguirse prestamos, cuyos intereses basculaban entre el 7 '5\% y el $30 \%^{59}$.

La respuesta a la petición de Joan Rodríguez fue debatida en una reunión extraordinaria de las autoridades locales celebrada en el archivo de la

\footnotetext{
${ }^{53}$ M. Mollat; PH WolfF, Uñas azules, Jacques y Ciompi. Las revoluciones populares en Europa en los siglos XIV y X'V, Madrid, 1989 (2 ${ }^{\mathrm{a}}$ ed.), p. 200.

${ }^{54}$ J. LE GoFf, Mercaderes y banqueros de la Edad Media, Madrid, 2004, p. 58.

${ }^{55}$ C. Astarita, Del feudalismo al capitalismo, p. 14.

${ }^{56}$ M. Mollat; PH. WolfF, Uñas azules, Jacques y Ciompi, p. 239.

${ }^{57}$ C. AstARITA, Del feudalismo al capitalismo, p. 14.

${ }^{58} \mathrm{~J} . \mathrm{V}$. GARCía MARSILLA, Vivir a crédito en la Valencia medieval. De los orígenes del sistema censal al endeudamiento del municipio, Valencia, 2002, pp. 231 y 237.

${ }^{59}$ Ibídem, pp. 238-239.
} 
lonja de la ciudad convocada con este único fin el 3 de enero ${ }^{60}$. También fue extraordinario el elenco de asistentes. Presidida por el justicia criminal contaba con la presencia de tres de los cinco jurados ${ }^{61}$ un número indeterminado de alguns notables consellers del Consell de la dita ciutat y homens de be de aquella. Todo parece indicar que los miembros del consistorio hostiles a las demandas de Joan Rodríguez convocaron esta reunión para dirimir una respuesta negativa a las pretensiones del líder popular, pero presentada como una acción responsable a lo servici...e lo benefici e repos del stat publich de la dita ciutat, meditada e lesa una e mes veus y razonada. Finalmente asistió a esta reunión el propio Joan Rodríguez para ser interrogado bajo juramento sobre sus pretensiones. En este primer episodio posterior a la presentación por Joan Rodríguez de su propuesta de reformas, observamos una fuerte tensión y presión en torno al líder artesanal, ya que al tomarle juramento se le ponía prácticamente en situación de comparecencia judicial. La primera pregunta que se le hizo, bajo juramento, fue si reconocía el escrito de alegaciones que se le mostraba y si había ordenado su elaboración, a lo que respondió afirmativamente. También y sobre esta cuestión fue requerida la presencia de Joan de Loriç, bachiller en leyes, que reconoció haber redactado el escrito de demandas presentado por Joan Rodríguez, destilando todas estas primeras líneas de la reunión una fuerte tensión. Las autoridades decidieron dejar constancia de todos estos hechos para memoria esdevenidor y que la respuesta concordada por todos los asistentes sería dada a conocer a Pere Roiç, abogado y síndico del Consell y comunicada públicamente a Joan Rodríguez ${ }^{62}$. En una reunión celebrada un día después en el mismo lugar y con los mismos asistentes se le comunicó a Joan Rodríguez que la respuesta a sus demandas le sería comunicada a través del escribano del Consell ${ }^{6}$.

En la respuesta que le presentaron a Joan Rodríguez las autoridades municipales alegaron lo siguiente:

1. Que los censales se cargaban a 18 o 20 dineros por libra (7'5$8 ' 3 \%$ ) y le negaban el poder para buscar compradores de censales, ya que no lo consideraban persona idónea para desarrollar dicha actividad, añadiendo que dicho poder se concederá a personas adecuadas para que puedan negociar la compra de dichos censales. Sobre la última denuncia el Consell la negaba, afirmando tajantemente que no había usureros ni se practicaba la usura en la ciudad. Finalmente las autoridades locales - los consellers y los jurados- se

${ }^{60}$ En esta fecha las reuniones del Consell General se celebraban habitualmente en la sala del Consell, situada en el edificio municipal de la ciudad. En la reunión del Consell Genera celebrada días después, el seis de enero, queda constancia que "En est dia fon justat Consell en la sala del Consell de la ciutat de Oriola...". Mientras que en la reunión del tres de enero aparece lo siguiente: "en est dia foeren justats en lo archiu de la longa de la dita ciutat los honorables...". AHO, Contestador, $\mathrm{n}^{0} 31$, ff. $16 \mathrm{r}$ y $13 \mathrm{r}$. respectivamente.

${ }^{61}$ Aunque está constatada la asistencia a esta reunión de Joan Terres, uno de los dos jurados que en el proceso a Joan Rodríguez mantuvo claras discrepancias con las actuaciones del grupo dirigente, no sabemos si este momento su apoyo a Rodríguez era claro o fue gestado en los decisivos días que sucedieron a esta reunión.

${ }^{62} \mathrm{AHO}$, Contestador, $\mathrm{n}^{\circ} 31$, f. 16r (1460, enero, 3).

${ }^{63} \mathrm{AHO}$, Contestador, $\mathrm{n}^{\mathrm{o}}$ 31, f. 16r-v (1460, enero, 4). 
mostraban sorprendidos de que sea procurador del pueblo y de que el pueblo haya constituido un procurador ${ }^{64}$. La primera acción de Joan Rodríguez fue solicitar al escribano del Consell una copia o traslado de la respuesta que le habían comunicado los jurados a sus demandas. Dos días después comparecía de nuevo el pelaire en el mismo lugar y antes las mismas autoridades, insistiendo en primer lugar en su petición, de disponer de una copia o traslado de la respuesta que le había sido comunicada dos días antes. Y pedía, "com a hun del poble", la convocatoria de una reunión del Consell General, para poder presentar un alegato o deliberación a la respuesta que le había sido dada. Exponía que todo ello lo hacía en servicio de la majestad del señor rey $\mathrm{y}$ en beneficio de la cosa publica de la ciudad ${ }^{65}$. La respuesta a estos requerimientos vino de forma contundente expresada por dos de los jurados, Joan Lopez de Baena y Pere Castell, que requirieron al Justicia para que comunicase a Joan Rodríguez que estaba preso a partir de ese momento. Le solicitaban juramento y homenaje de manos y boca de no salir de la lonja, donde debía permanecer preso. El pelaire presto el juramento y homenaje correspondiente. A continuación se le indico que entrase en el archivo de la lonja, donde se habían reunido el Justicia criminal, los tres jurados y algunos notables consellers, hecho que aprovecharon los jurados, Joan Lopez de Baena y Pere Castell, para requerir al Justicia criminal que condujese al detenido a la prisión común de la ciudad. Ante esta situación tan grave, el pelaire reclamaba de nuevo y con insistencia la petición de una convocatoria del Consell General para poder exponer sus argumentos, a la vez que indicaba que no podía ser detenido y que la jurisdicción en este caso competía al Gobernador General o al Baile General, diciendole al Justicia Criminal y que vos non podeu prendre. La respuesta del Justicia era que lo había detenido cumpliendo ordenes dadas por dos jurados, sobre delitos que había cometido indicados por dichos magistrados y que le serían comunicados en su momento. De esta forma se iniciaba el cautiverio de Joan Rodríguez ${ }^{66}$.

El 6 de enero se reunía el Consell General, convocado por el justicia criminal y los jurados, para informar de las actividades de Joan Rodríguez y de su encarcelamiento. En un amplio y extenso informe los principales magistrados de la ciudad, comunicaban al Consell el gran daño y ofensa causada por Joan Rodriguez en los días pasados en la ciudad por sus sediciones y movimientos y no siendo suficiente la suplicación que había presentado ante el Consell el pasado veintiuno de diciembre, en la que se

${ }^{64} \mathrm{AHO}$, Contestador, no 31, f. 16 r-v. (1460, enero, 3 y 4).

${ }^{65} \mathrm{AHO}$, Contestador, $\mathrm{n}^{\mathrm{o}} 30$, f. $14 \mathrm{v}$. (1460, enero, 5).

${ }^{66}$ En su encierro en la prisión común de la ciudad, en ningún momento fue planteada la posibilidad de que fuese conducido a otro recinto público más đigno aludiendo a sụ condición de hombre honrado, lo que indica que para la mayor parte de los miembros del consistorio Joan Rodríguez no tenía acreditada esta condición, lo que implicaba su encierro en la prisión. Contrasta esto con otros encarcelamientos de vecinos de Orihuela, en los que las autoridades requirieron un trato digno para el apresado, por su condición de hombre honrado, pidiendo fuese conducido a otros espacio de mayor dignidad, verbigracia, la sala del Consell. Es lo que sucedió en 1461 con el encierro en la prisión de Pere de Galbe por el Gobernador. El Consell pidió en este caso que fuese conducido a la sala del Consell, alegando la condición de hombre honrado del detenido. AHO, Contestador, $\mathrm{n}^{\circ}$ 31, f. 303v. (1463, abril, 18). 
designaba procurador del pueblo, considerado por las autoridades municipales como cap de gabella, ha ido más lejos protestando por la obligación de realizar las guardias y patrullas nocturnas rodes ${ }^{67}$ y que por esta reclamación había tenido un enfrentamiento verbal con Pere Roiz, síndico y lugarteniente del Justicia. Se le acusa, por ello, de haber actuado de forma irreverente y hablando de forma escandalosa. Por todos estos motivos los jurados Joan López de Baena y Pere Castell ${ }^{68}$ habían requerido al Justicia criminal el encarcelamiento de Joan Rodríguez ${ }^{69}$. Es muy interesante la calificación que las autoridades le dan a Joan Rodríguez como cap de gabella, ya que implica su consideración como dirigente de una conspiración con otras personas. Asimismo hay que recordar que este término fue utilizado peyorativamente para aludir a los componentes de la Germanía Valenciana ${ }^{70}$. Tras escuchar el informe de los jurados, el Consell ordenó que una delegación de consellers presidida por el sindico ${ }^{71}$ y los jurados debían interrogar a Joan Rodríguez, sobre su intención de presentar o no un nuevo requerimiento al Consell, en respuesta a las graves acusaciones que habían sido vertidas contra su persona. En este momento, la delegación abandonó la sala del Consell, para dirigirse a la prisión a entrevistar al líder popular, mientras que el resto de los miembros del consistorio esperaban en la sala la respuesta. Ya en la prisión el síndico se dirigió a Joan Rodriguez indicandole que siguiendo su solicitud se había convocado el Consell general, y que se presentaban como comisión de dicho Consell para recibir en su nombre su respuesta y nuevo requerimiento a la respuesta que se le había dado a la primera solicitud que había presentado el día 21 de diciembre pasado. Responde el líder popular, que dará la respuesta, en servicio de su majestad y en beneficio de la cosa pública, únicamente en presencia del Consell General y del Lugarteniente de Gobernador, que debe ser convocado ante el Consell General con este fin. Le responde el síndico que lo que tenga que decir que lo diga ante esta comisión, ya que son oficiales de su majestad y que les puede comunicar todo cuanto desee. Responde Joan Rodríguez que sólo se manifestará ante el Consell General en pleno y con la presencia en el mismo del lugarteniente de Gobernador.

Realizado el interrogatorio, la comisión que había enviado el Consell, retornó a la sala del Consell donde informó de lo sucedido. El Consell entendiendo la importancia de escuchar los alegatos de Joan Rodríguez que ha

\footnotetext{
${ }^{67}$ Repartir las obligaciones militares de ronda y guardia entre los trabajadores podía ser una de las funciones del ministerial urbano en Francia. B. CHEVALIER, Corporations, conflits politiques et paix sociale en France, p. 24.

${ }^{68} \mathrm{De}$ los cinco jurados con que contaba Orihuela, tres se mostraron favorables a su detención y procesamiento, mientras que los otros dos manifestaron en todo momento sus reservas por el procedimiento y las actuaciones seguidas contra Joan Rodríguez. De los tres jurados contrarios al líder popular, Joan López de Baena y Pere Castell, se mostraron como los jurados contrarios al líder popular, Joan López de Baena y Pere Castell, se mostraron como los más activos y virulentos y fueron,
encarcelamiento del pelaire oriolano.

${ }^{69} \mathrm{AHO}$, Contestador, $\mathrm{n}^{\mathrm{o}}$ 31, ff. 21r-22-r. (1460, enero, 6).

${ }^{70}$ V.J. VALLÉS BORRÀs, La Germanía, p. 15.

${ }^{71}$ Era además lugarteniente de justicia criminal.
} 
insistido en realizarlos ante el pleno del Consell y que los realizaba en servicio de su majestad y en beneficio de la cosa pública, y atendiendo a su demanda, ordena que una nueva delegación del Consell con la incorporación del lugarteniente de gobernador, acuda a la prisión a escuchar y recibir la respuesta de Joan Rodríguez en nombre del Consell.

Esta delegación que contaba por primera vez con la presencia del lugarteniente de Gobernador, acudió a la prisión el día siete de enero, a parlamentar con Joan Rodríguez, que tras mantener una conversión con los miembros de la comisión les entrego un acta, que había sido redactada por el notario Pere de Ayora para ser leída ante el consistorio.

En cumplimiento del requerimiento de ser escuchado por el Consell General, en la reunión del consistorio del diez de enero fue presentada y leída el acta que había redactado el notario Pere de Ayora $^{72}$. Sorprendentemente se trataba de una confesión en toda regla de arrepentimiento total y deseo de reparar los errores cometidos y el daño causado. Pese a ello la actitud del Consell fue la de no olvidar lo que había hecho y persistir en la denuncia para escarnio público y escarmiento futuro, por lo que se pedía explícitamente dejar constancia escrita de lo sucedido para las generaciones futuras ${ }^{73}$. La actitud posterior de Joan Rodriguez apelando sobre su detención, pone en dudas esta supuesta confesión y plantea con toda probabilidad que fuese fingida, una impostura para ganar tiempo para su causa. Es posible también que toda la declaración fuese falseada por las autoridades locales, deseosas de poner fin a la mayor celeridad a una detención y pleito con una fuerte carga política, aunque esta segunda hipótesis nos parece menos verosímil.

La posibilidad de que Joan Rodríguez estuviese ganando tiempo, apaciguando los ánimos soliviantados de los tres jurados instigadores de su encarcelamiento, cobra fuerza al seguir las acciones que la Corona emprendió inmediatamente después de su encarcelamiento. Así el veintiocho de enero escribía Juan II desde Barcelona una misiva al Gobernador de Orihuela y al Baile General, para pedir un informe sobre las noticias que ha recibido de la ciudad de Orihuela, sobre un vecino, Joan Rodriguez, por los parlamentos que ha hecho con los oficiales y otros de la ciudad llamandose procurador del pueblo y por que ello ha sido detenido por el Justicia criminal a instancia de los jurados. Declara el rey que su voluntad es que si ha delinquido que sea castigado como se merece, pero que si es inocente que no se cometa con él ninguna injusticia y que no sea molestado ${ }^{74}$. En esta primera intervención que conocemos del rey, se observa el interés del monarca por interceder por el líder popular, a través de sus oficiales reales, especialmente el gobernador.

\footnotetext{
${ }^{72}$ Casualmente el mismo notario que había redactado el escrito de arrepentimiento y confesión de Joan Rodríguez.

${ }^{73} \mathrm{AHO}$, Contestador, $\mathrm{n}^{\mathrm{o}} 31$, f. $22 \mathrm{v}-25 \mathrm{r}$. (1460, enero, 10).

${ }^{74} \mathrm{ARV}$, Real, 90, ff. 34 r-v. (1460, enero, 28). 


\section{LA CONFESIÓN DE JOAN RODRÍGUEZ}

La supuesta confesión de Joan Rodriguez, es un relato de gran valor y excepcional para conocer los entresijos del asociacionismo medieval y de los movimientos sociales urbanos de la segunda mitad del siglo XV.

En su confesión personal, declaraba que algunos vecinos le habían apoyado para seguir su causa y le habían animado a preparar las actas de propuestas y reclamaciones que había presentado tanto en la ciudad como ante el rey. Ahora, todos aquellos que le dieron apoyo y favor para liderar la causa, le han abandonando desde que ha sido apresado y ninguno de sus partidarios y seguidores ha venido a hablar con el o visitarle a la cárcel. Por ello abandonaba esta mala vía y los malos consejos que le habían dado y por el provecho de su vida y su honor, consideraba que todas sus acciones habían resultado dolosas y gravosas para el Consell y la ciudad y declaraba que renunciaba a todos los actos emprendidos y a todas las actas presentadas por los malos consejos y prometía vivir bien y honestamente al servicio del señor rey y beneficio de la ciudad y no hacer en el pueblo ni por las plazas ningún parlamento ni conmoción ni juntar a la gente para ir en contra del Consell. Se compromete a actuar en nombre del Consell y no recibir procuraciones ni actuar como procurador de ninguno, pero se reserva el derecho a recibir el salario por los trabajos que ha realizado como procurador. Acepta guardar la debida reverencia a los oficiales y al Consell y no se manifestará de forma irreverente contra ellos, ni intentara hablar o entender de las cosas concernientes a los oficiales y al Consell y actuará en defensa de dichos oficiales y Consell, rogando y suplicando al justicia, a los jurados y al Consell que de todo lo que ha hecho y de las irreverencias cometidas que le perdonen como a hijo y natural del Consell abrazandolo como a hijo de aquel y dejando de lado los errores cometidos, colaboraría delatando a las gentes que actúan contra el Consell, poniendose plenamente en las manos de las autoridades para que hagan lo que quieran con él.

\section{EL PROCESO Y LA CONSTRUCCIÓN DE LA MEMORIA HISTÓRICA}

La confesión y supuesto arrepentimiento de Joan Rodríguez, además de su deseo de colaborar con las autoridades locales, tenían que haber puesto el punto final al movimiento social de protesta encabezado por este líder popular. Lejos de ello las autoridades municipales decidieron en primer lugar poner por escrito en las actas y libros del Consell la declaración integra de Joan Rodríguez para dejar memoria histórica de lo sucedido ${ }^{75}$. Además el

\footnotetext{
${ }^{75}$ Sobre el proceso de construcción de la memoria histórica en la Europa medieval vid. M.T. CLANCHY, From Memory to Wrintten Record. England 1066-1307. Oxford (UK) \& Cambridge (USA), 2001 
Consell General de la ciudad inició el proceso judicial contra Joan Rodríguez, ordenando a los jurados, que en nombre de la ciudad y de su Consell, que Joan Rodríguez sea denunciado por todas estas conmociones y por cualquier crimen o delito que haya cometido. Para realizar el proceso se deben recabar todos los testimonios posibles y recoger toda la información pertinente y caso de proceder a informar de todo ello a su majestad el rey, debe ser consultado antes el Consell general, en los términos en que se va a realizar dicho consulta al soberano. Todo ello para conseguir que Joan Rodríguez por los delitos que ha cometido reciba la pena que le sea debida para su castigo y ejemplo futuro. Autoriza el Consell a los jurados para que en la custodia en la cárcel de Joan Rodríguez tomen todas las medidas que consideren oportuno, pudiendo recibir para ello el asesoramiento constante del síndico del Consell.

La fuerte defensa y el aplazamiento de la resolución final del proceso que tres años después no había sido resuelto, nos indican que Joan Rodríguez, lejos de poner su destino en manos de las autoridades locales como refería en su supuesto arrepentimiento, planteó una férrea defensa sobre la que consideraba injusta y arbitraria detención. El 23 de febrero de 1460 Joan Rodríguez comparecía ante Luis Cornell, Gobernador del reino de Valencia dellà Sexona y los jurados de Orihuela Joan López Baena, Jaume Morrelles y Pere Castell para poder presentar la apelación correspondiente y las alegaciones a la injusta detención que a su juicio se había producido contra su persona. Los otros dos jurados, Joan Terres y Joan Auret, en función de lo declarado en el proceso, se habían negado a acudir considerado lo injusto del mismo y la ofensa que se estaba realizado a Joan Rodríguez. La acusación y encarcelamiento de Joan Rodríguez había partido de estos tres jurados, los otros dos nos estaban de acuerdo con la acusación y por ello se habían negado a participar en el proceso.

Como hemos visto Joan Rodríguez era un destacado pelaire de la ciudad y un miembro activo del grupo de ciudadanos menores que tenían derecho a los cargos municipales al cumplir el requisito mínimo imprescindible de poseer caballo armado. No obstante la normativa electoral, les relegaba a un puesto de mínima categoría, ya que los cargos de mayor responsabilidad e importancia desde la introducción de la insaculación en 1445 quedaron en poder de los caballeros y los ciudadanos mayores ${ }^{76}$, lo que explica el resentimiento de los ciudadanos menores que básicamente formaban parte del artesanado más activo y emprendedor y que a través de destacados lideres como Joan Rodríguez propugnaban la realización de reformas en el sistema electoral. Su encarcelamiento y posterior proceso, demuestra la férrea resistencia de la oligarquía oriolana por conservar incólumes sus privilegios

${ }^{76}$ J.A. BARRIO BARRIO, Las élites políticas urbanas en la Gobernación de Orihuela. Los sistemas de creación, acceso y reproducción del grupo dirigente en un territorio fronterizo "Anuario de Estudios Medievales", 32/2 (2002), pp. 777-808. Para la introducción de la insaculación en Elche y los conflictos suscitados, vease J.V. CABEZUELOPLIEGO, La regulación en la elección de los cargos municipales en un espacio señorial: Elx. 1444 . "Per co que los dits oficis es repartissin e $\cdot n$ fossen entre molts bons homens repartits que may ne podien haver oficis es, repartissin e n fossen entre molts bons homens repartits que may ne podien haver e
altres n'havien massa sovint". "Acta Historica et Archaeologica Mediaevalia", 26 (2005) (=Homenatge a la Professora Dra. Carme Batlle Gallart), pp. 775-794

ANUARIo de Estudios Medievales (AEM), 36/2, julio-diciembre 2006, pp. 687-712. ISSN 0066-5061 
y la oposición del grupo dirigente a las pretensiones del cabecilla de los artesanos.

Del largo texto de las alegaciones presentadas ${ }^{77}$, podemos observar que en su defensa, Joan Rodríguez presentaba argumentos sólidos y que para poder realizar esta apelación, posiblemente había contado con el apoyo del rey en la figura del Gobernador.

Cada uno de los capítulos de su defensa responde a cada una de las acusaciones que en su momento fueron formuladas contra él. Por ello y a través de la replica que realiza podemos conocer de forma exhaustiva en que consistieron todas las acusaciones.

1. La parte inicial y central de su defensa es que desde el gobierno municipal, a través de los tres jurados presentes en el proceso se le había perseguido implacablemente, vertiendo contra él todas las acusaciones posibles. ... que si mes crims dels declarats en lo dit primer capitol se ageren pogut trobar en lo mon mes ni agren ajustat tanta es posada la volentat que an haut contra lo dit Johan Rodriguez... Frente a la denuncia de que era mal hombre, alega que es buen hombre y de buena fama y vida y hombre honrado y que ha acostumbrado a tener caballo armado, sirviendo con él al señor rey y sus hermanos ${ }^{78}$ en los "tiempos de la guerra con Castilla" - se referirá posiblemente a la guerra de 1429-. Afirmaba que había perdido dos, tres, cinco e incluso ocho caballos combatiendo ${ }^{79}$. Este alegato difamatorio permite diseccionar los parámetros mentales del patriciado oriolano, alejado de esa cosmogonía de otros patriciados europeos con un perfil más mercantil y que valoraba y tenía en alta estima el trabajo y el esfuerzo propio ${ }^{80}$.

2. La segunda acusación hace referencia a su comportamiento deshonesto, ya que se le imputa realizar fraudes jugando. Frente a ello alega que vive bien y "honestamente", ha tenido viñas y en la actualidad tiene tierras "campas" que está cultivando. Además ejerce en su taller el oficio de pelaire y elabora paños, ya que sabe cardar, peinar y todas las artes del oficio. Ha participado con sus hermanos en la reciente guerra contra Castilla con sus caballos. Ha jugado, pero estima que no es una actividad indigna, ya que muchos hombres buenos la practican.

3. Se le acusa de haber participado en una brega, lo que rechaza Joan.

4. Se le acusa de fabricar moneda falsa y de introducirla desde Castilla en el reino de Valencia. Rechazaba ambas y afirma que desconoce como se fabrica la moneda falsa.

\footnotetext{
${ }^{77} \mathrm{AHO}$, Contestador, $\mathrm{n}^{\mathrm{o}} \mathrm{D}-1$, ff. 93r-96v. (1460, febrero, 23).

${ }^{78}$ Sobre los posibles hermanos de Joan Rodríguez no hay noticias.

${ }^{79}$ Años después, cuando Joan Rodríguẹz fue nombrado Baile de Orihuela, las autoridades municipales, a través del mensajero municipal trasladaron a Juan II su malestar por dicho nombramiento, alegando que el nombramiento hecho en favor de Joan Rodriguez, como baile de Orihuela no podia tener efecto, ya que era menestral, pelaire, hombre de infima condición, máxime cuando en la ciudad había nobles, caballeros, ciudadanos, generosos y otras personas honradas. No tenia casa ni bienes propios en la ciudad, ademas de haber cometido escandalos $\mathrm{y}$ delitos deshonestos.

${ }^{80}$ J. Ma Monsalvo Antón, Las ciudades europeas del Medievo, Madrid, 1997, p. 274. 
5. Se le acusa de haber defraudado y de haber incitado a otras personas para acudir a la villa a hacer fraude. Lo niega todo.

6 . Se le acusa de haber opuesto resistencia al justicia y de haber vertido palabras injuriosas contra dicho oficial. Afirma que todo es falso y además fue absuelto por el rey de dicha acusación de resistencia ...per lo dit Senyor Rey que hui benaventuradament regna.... Expone además que en función de los privilegios que disfrutan los hombres con caballo se le había privado en su derecho de manifestar su disconformidad ante el justicia. Dice que ha disfrutado y sigue disfrutando de dicho privilegio como propietario de caballo.

7. Reiteración del capítulo anterior.

8. Se le acusa de haber robado esclavos o cautivos. Lo niega. Pero reconoce el caso de Joan Martínez, carnicero, que tenía un mozo apresado en la última guerra con Castilla que era de Cartagena y que tras la firma de la paz entre ambos reyes, fue devuelto como hombre libre a su padre en Cartagena. Pero después vino libremente a Orihuela y su instaló en casa de Joan Martínez donde dormía y comía y volvía a Cartagena con sus padres y acudía a Orihuela.

9. El nuevo capítulo forma parte de la acusación principal. Es acusado de actuar como procurador del poble y de promover escandalos. Esto provocó su detención y la investigación de los hechos imputados. En su defensa Joan se define como miembro del pueblo, ...com hun dels del poble de la present Ciutat... y que como tal y en representación de otros de su misma condición ha protestado por la situación injusta de los miembros de la mano menor en el acceso a los oficios. Como hemos visto anteriormente, en junio de 1459 Juan II suspendía la elección del sobrecequiero, que se había celebrado en Pascua por las quejas presentadas por un grupo de ciudadanos menores sobre la graduación que se había efectuado antes de la elección, al frente del cual estaba Joan Rodríguez. Afirma que si el rey conociera todas las injusticias y abusos que se cometen repararía su situación y la de los otros a los que él ha representado como procurador, concediendo una provisión.

10. La última acusación se centra en su actuación como procurador del poble y en la concitación ilícita de individuos, ya que existía el delito de convencitulum seu manipolia que prohibía la reunión de individuos, verbigracia, artesanos reunidos en la lonja para escuchar un discurso sobre las injusticias políticas y la propuesta de reformas. Precisamente a Joan Rodríguez se le acusaba de promover concentraciones de gentes en la lonja y otros lugares públicos ${ }^{81}$, donde les arengaba sobre las injusticias del sistema político y electoral de Orihuela y les proponía reformas que defendería como procurador de todos ellos. Los partidarios de Joan Rodríguez firmaron procuraciones a su favor, para que pudiera defender sus derechos ante otra persona u autoridad. Se trata de la procurationem certum et specialem que

\footnotetext{
${ }^{81}$ Era habitual en las ciudades medievales, que las disputas políticas tuvieran lugar en la calle y lugares públicos como plazas o lonjas. En Génova las disputas que los vecinos mantenían acerca de la política exterior de la ciudad, tenían lugar en plazas y calles. D. WALEY, Las ciudades-república italianas. Madrid, 1969, p. 52. 
revertía en un individuo y diferente por tanto de la procuración como cargo público. En su defensa Joan Rodríguez alegaba que la gente había acudido ordenadamente sin concitar grandes concentraciones. Que habían acudido ante el notario que redactaba las procuraciones pertinentes, bien en la lonja u otros lugares públicos de forma ordenada y sin promover altercados ni concentraciones ilícitas, acudiendo los interesados de hora en hora. .Además el lugarteniente de gobernador había autorizado la realización de dichas procuraciones.

Joan Rodríguez había acudido ante el rey a exponer las quejas de dichos ciudadanos y a exponer sus reformas con la acreditación de dichas procuraciones que se habían presentado ante el monarca, que lo había tenido por bien y prometido realizar las justas reformas ante la propuesta de dichos ciudadanos. Por ello Joan Rodríguez entendía que el gobernador no podía actuar contra un mandato real.

También hay una acusación sobre el acta que presentó ante el Consell. Se defiende alegando que ha presentado dicha escritura correctamente, como un miembro del pueblo y además como procurador del pueblo, ya que una parte del pueblo de Orihuela lo ha elegido como su procurador. Alega que las manifestaciones recogidas en dicha escritura son buenas, santas y a servicio de Dios y del señor rey y provecho de la cosa pública.

Sobre las acusaciones vertidas en el capítulo 10 las considera de "menor cuantía" y de poca consideración, ya que se alude a los parlamentos que tenía con sus compañeros en la lonja, cuando hacia referencia a las guardias y patrullas nocturnas que injustamente les eran asignadas y sin ninguna necesidad de forma vejatoria. Por ello había propuesto hacerse con el cargo de muñidor para poder controlar las convocatorias y por eso había previsto la compra del cargo, de lo que tendría que proveer el Consell. Todo ello no lo consideraba negativo ni suponía una actitud de crítica ni de incitación al pueblo.

Solicitaba finalmente fuese declarado inocente de todos los cargos y liberado de la prisión que padecía.

En la respuesta que dieron los jurados, exponían que habían iniciado la detención y encarcelamiento de Joan Rodríguez por los delitos que había cometido contra el Consell de la ciudad.

El 15 de abril los jurados no habían conseguido agilizar y culminar el proceso contra Joan Rodríguez, ya que tenían dificultades por las numerosas cuestiones que tenían que tratar en el gobierno de la ciudad, por lo que el Consell decidió nombrar a una persona, el notario Pere de Ayora, con rango de procurador para que ayudase a los jurados en los tramites y trabajos concernientes al proceso ${ }^{82}$. Pocos días después llegaban noticias preocupantes al Consell. Pere Roiz, mensajero enviado por el Consell a parlamentar con Juan II en la ciudad de Valencia, informaba que Alfonso Gómez había hablado

\footnotetext{
${ }^{82}$ AHO, Contestador, $\mathrm{n}^{\mathrm{o}}$ 31, f. 47r. (1461, abril, 15). 
con Juan II, actuando como mensajero del lugar de Guardamar ${ }^{83}$, para defender la causa de Joan Rodríguez y elevar al rey otra serie de quejas en contra del Consell de Orihuela. El Consell reaccionaba airado ante lo que consideraba una grave ofensa y mal ejemplo, convocando al gobernador y al justicia y a los jurados para interrogar a todos los oficiales sobre quien había constituido a Alfonso Gómez como mensajero de Guardamar. En esta misma sesión se aprobó, por unanimidad, la solemne confirmación de todos las acciones emprendidas contra la persona de Joan Rodríguez, ante el Gobernador General y su corte por parte de la ciudad y Consell, tanto por vía de denuncia como en cualquier otra manera ${ }^{84}$.

La acciones de Alfonso Gómez ${ }^{85}$, ante el rey en la ciudad de Valencia, tuvieron éxito, recibiendo con pesar el Consell de Orihuela una carta cerrada, que había obtenido Alfonso Gómez del rey, enviada al gobernador y al baile general, en la que el monarca requería y solicitaba que previa presentación de juramento y homenaje por parte de Joan Rodríguez, se le permitiese abandonar la prisión para ir a Valencia a entrevistarse con el rey. El Consell entendía que esta petición iba contra los privilegios de la ciudad, los fueros y privilegios del reino y que aceptar esta orden podía ser muy perjudicial para la ciudad, indicando que Joan Rodríguez tenía que ser juzgado en la corte de la ciudad, donde recibiría una sentencia condenatoria o absolutoria. Dada la gravedad de la situación, el Consell consideró oportuno proponer el envío de uno o dos mensajeros, pero con el sueldo de uno. Esta propuesta suscitó un animado debate con participación de diversos consellers, apoyando la iniciativa, pero con diferentes propuestas sobre el envío de uno o dos mensajeros, sobre el sueldo que debían recibir, sobre cómo debían ser elegidos, dos mensajeros con sueldo de uno, uno con medio sueldo, etc., así como nombres de candidatos a la mensajería. Hubo un cierto consenso en proponer que los mensajeros fuesen designados por el Justicia criminal y los jurados así como en el nombre de dos juristas de la ciudad como candidatos a la nominación, Francesc Silvestre y Francesc de Vilafranca. Las actas de la reunión no recogen el nombramiento oficial de los mensajeros ${ }^{86}$. Finalmente fueron nombrados, como consta en la correspondiente carta enviada al rey, mosén Joan Rocamora, caballero y micer Pere de Fontes, jurista ${ }^{87}$.

Es interesante constatar que en el contexto en que se ha producido la petición de reformas por Joan Rodríguez, el municipio atravesaba claramente

\footnotetext{
${ }^{83}$ Guardamar era una antigua villa real que había perdido su condición trạs la guerra de los dos Pedros. Pedro IV en recompensa a la villa de Orihuela por los servicios prestado en la guerra y por la supuesta desafección de los habitantes de Guardamar, la había despojado de su condicion de villa para convertirla en carrer, lugar dependiente de la villa de Orihuela. Sorprende, por tanto, este mensajero al servicio de Joan Rodríguez, que se presenta ante el rey

como mensajero de Guardamar, consiguiendo audiencia regía y logrando una actuación favorable del monarca ante el pelaire detenido.

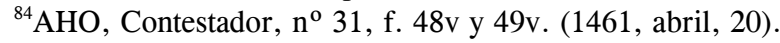

${ }^{85} \mathrm{Al}$ que podemos calificar como mensajero al servicio de la causa de Joan Rodríguez.

${ }^{86} \mathrm{AHO}$, Contestador, $\mathrm{n}^{\mathrm{0}}$ 31, ff. 50r-51r. (1460, abril, 25).

${ }^{87} \mathrm{AHO}$, Contestador, $\mathrm{n}^{0}$ 31, f. 52r. (1460, mayo, 7).
} 
desde 1456 por una situación de quiebra de las finanzas locales ${ }^{88}$ que obligaba a reducir al máximo los salarios y emolumentos que recibían los oficiales municipales.

Las instrucciones para los dos mensajeros, fueron elaboradas por el Justicia criminal y los jurados Joan López de Baena, Pere Castell y Jaume Morrelles. Es interesante observar que los dos jurados que propiciaron el encarcelamiento de Joan Rodríguez, Joan López de Baena y Pere Castell, aparezcan redactando el memorial de instrucciones de los mensajeros que van a entrevistarse con el rey para deliberar sobre la detención de Joan Rodríguez. Las instrucciones a los mensajeros, un largo texto, resumían los argumentos expuestos en la última reunión del Consell, que la petición regía para que Joan Rodríguez saliese temporalmente de prisión para entrevistarse con el monarca atentaba claramente contra los privilegios de la ciudad y contra los privilegios y fueros del reino, especialmente contra los privilegios que impedían que un vecino de la ciudad pudiese salir del término de la gobernación para ser procesado o juzgado ${ }^{89}$. El recurso a este privilegio, no dejaba de ser una hábil manipulación de los munícipes, de lo que era un derecho que protegía a los vecinos de Orihuela cuando eran reclamados ante tribunales que tenían sede fuera de la Gobernación, especialmente los pleitos que afectaban a la jurisdicción del obispado de Cartagena-Murcia. Dado que en este caso, el propio procesado renunciaba a ese derecho y privilegio, y pedía poder dirigirse a la ciudad de Valencia a entrevistarse con el rey, se utilizaba el privilegio concediendole un sentido contrario.

La división en el seno del gobierno municipal que se había manifestado desde el principio del proceso a Joan Rodríguez, se puso en evidencia, cuando en la siguiente reunión del Consell fue necesario ratificar el nombramiento de los dos mensajeros realizados por el justicia criminal y tres jurados, ya que los otros jurados, Joan Terres y Joan Auret, discrepaban con la designación. Joan Terres y Joan Auret, habían manifestado desde el principio del proceso su oposición a las medidas adoptadas por el justicia criminal y los otros jurados. El justicia criminal y los tres jurados que habían designado a los mensajeros, proponían la ratificación y aprobación de los mismos por parte del Consell, que accedió a dicha propuesta ${ }^{90}$. Llama también la atención que el nombre de los dos designados no coincide con el nombre de los candidatos propuestos previamente por una buena parte de los consellers. Los dos jurados discrepantes manifestaban su rechazo, ya que los mensajeros ya habían partido y el procedimiento ordinario establecía que la confirmación de los mensajeros se debía producir antes de su marcha e indicaban el nombre del algunos consellers que apoyaban su propuesta y se negaban a dar la confirmación

${ }^{88}$ J.A. BARRIO BARRIO, Mercado urbano en Orihuela durante el reinado de Alfonso $V$ (1416-1458), Alicante, 1998, pp. 58-59.

${ }^{89} \mathrm{AHO}$, Contestador, $\mathrm{n}^{\mathrm{o}} 31$, f. 53v. (sin fecha).

${ }^{90} \mathrm{AHO}$, Contestador, no 31 , f. 54 r-v. (1460, mayo, 11). 
requerida ${ }^{91}$. Frente a ellos, Ramon Morera y Remir Alvarez dijeron que aprobaban la confirmación de los mensajeros ${ }^{92}$.

No volvemos a tener noticias del conflicto hasta que un año después de haberse iniciado Juan II se planteaba la opción de nombrar al pelaire Joan Rodríguez baile local de Orihuela, para lo que solicitó información al baile general, sobre la habilidad de Joan Rodríguez para desempeñar dicho cargo. Le encarga al rey al Baile General que se informe prontamente de la inhabilidad o indisposición de dicho Rodríguez para ejercer dicho oficio, u otro oficio real ${ }^{93}$. Finalmente Joan Rodríguez recibió el nombramiento oficial de Baile local el trece de agosto de 1461 tras la vacante por defunción de su predecesor Antoni Terres ${ }^{94}$. No había transcurrido un año desde este nombramiento cuando Jaume Masquefa, caballero, y como mensajero de Orihuela se quejaba al monarca de que el nombramiento hecho en favor de Joan Rodríguez, como baile de Orihuela, alegando que era menestral, pelaire, hombre de ínfima condición, máxime cuando en la ciudad había nobles, caballeros, ciudadanos, generosos y otras personas honradas. Denunciaba que no tenia casa ni bienes propios en la ciudad, ademas de haber cometido escandalos y delitos deshonestos. Juan II pide al baile general que se informe de todo ello y le remita dicha documentación ${ }^{95}$.

Las últimas noticias son de tres años después cuando todavía continuaba mosén Joan Rocamora, como mensajero ante el rey y recibía en junio instrucciones del Consell. En una de ellas se le recuerda que la causa que sigue la ciudad contra Joan Rodríguez se ha prolongado en exceso y que desean que concluya, afirmando los munícipes que es ja feta inmortal. Le piden que suplique al rey que pese a cualquier provisión redactada ordene al gobernador que se resuelva el caso y que dicte sentencia ${ }^{96}$. Este último dado demuestra que Joan Rodríguez había sido encarcelado y procesado, pero sin recibir sentencia firme en la causa que las autoridades municipales querían mantener abierta en su contra, que había salido de la cárcel, aunque ignoramos en que fecha exacta y que había sido nombrado baile local por Juan II un año después de haberse iniciado su cautiverio.

\section{A MODO DE CONCLUSIÓN}

Las vías del asociacionismo fueron múltiples en la Edad Media. La asociación popular organizada y dirigida por el pelaire de la ciudad de Orihuela, Joan Rodríguez, nos muestra un modelo puntual de asociación

\footnotetext{
${ }^{91}$ Jaume Masquefa, Joan Masquefa, Pere Masquefa, Nicolau Perez y Gines d'Ontinyent eran algunos de los consellers contrarios a confirmar la designación de los mensajeros.

${ }^{92} \mathrm{AHO}$, Contestador, $\mathrm{n}^{\mathrm{o}} 31$, f. 54v (1460, abril, mayo, 11).

${ }^{93} \mathrm{ARV}$, Real, 400, ff. 6v. (1461, febrero, 19).

${ }^{94}$ ARV. Real, 422, ff. 64v-65r. (1461, agosto, 13).

${ }^{95}$ ARV. Real, 286, ff. 119r-v.(1462, enero, 2).

${ }^{96} \mathrm{AHO}$, Contestador, $\mathrm{n}^{\mathrm{o}}$ 31, f. 333r. (1463, junio, 9). 
urbana, patrocinada por ciudadanos de la mano menor que están en el nivel más bajo para acceder a las oficialías municipales, pero muy alejados de los escenarios políticos donde se adoptaban las decisiones más importantes de la ciudad. El camino elegido apunta a una opción reformista, no violenta ni tumultuosa, bajo los mecanismos habituales de las pautas políticas del Cuatrocientos, concentración de individuos en espacios públicos, arengas y discursos políticos, elaboración de un programa político de propuestas, agrupamiento asociativo bajo las pautas de la procuración notarial, elección entre todos de un síndico o representante de todos los descontentos y finalmente elevación a las altas magistraturas políticas, monarquía y municipio, de las diferentes aspiraciones de su programa de reformas políticas, económicas y sociales.

Todos estos datos demuestran la existencia de una conflictividad social entre la oligarquía de caballeros y ciudadanos mayores y pelaires como Joan Rodríguez relegados como ciudadanos menores a un plano secundario en la vida política municipal. La actuación destacada de este artesano al organizar un movimiento popular, muestra un intento de protesta por parte de los artesanos oriolanos para intentar mejorar posiblemente su situación laboral y sus posibilidad de acceder a créditos a bajo interés y poder intentar capitalizar sus negocios. Para ello era imprescindible poder acceder a los cargos políticos del consistorio donde se adoptaban las principales medidas que les afectaban, como la regulación del oficio, la compra de censales municipales, los salarios que debían cobrar, y el tipo de impuesto ordinario que afectaba a los vecinos, así como las tributaciones o tachas extraordinarias que se iban estableciendo. En 1280-1281 los disturbios (moerlemaye) de Brujas estuvieron condicionados por la tributación fijada por el patriciado que afectaba especialmente al artesanado textil, que veía como dependía totalmente en su existencia diaria de las decisiones que adoptaban las elites mercantiles ${ }^{97}$. La revuelta popular de Pamplona en 1386 también estuvo condicionada por las medidas fiscales extraordinarias establecidas por la monarquía durante los años 1385 y $1386^{98}$.

El régimen municipal se mantuvo latente en Castilla, a pesar de las enormes contradicciones que encerraba, gracias a los acuerdos y consensos entre los grupos sociales afectados. Este consenso que se iba renovando impedía que los estados latentes de tensión explotasen, reventando el sistema social urbano ${ }^{99}$.

Partiendo de estas sugerente hipótesis, planteamos a través del estudio de este episodio de protesta urbana acaecido en la Orihuela de la segunda mitad del siglo XV, la idea de que la introducción de la insaculación y los mecanismos de redreç de la monarquía en la Corona de Aragón, no sólo no consiguieron superar estas tensiones, sino que dificultaron la continuidad de todo consenso, al sacar del interior del municipio la resolución de los

\footnotetext{
${ }^{97}$ Tih.A. BOOGAART, Reflections on the Moerlemave: Revolt and Reform in Late Medieval Bruges, "Revue Belge de Philologie et diHistòrie", 79 (2001), pp. 1133-1157.

${ }^{98}$ J.A. FERNÁNDEZ DE LARREA ROJAS, Conflicto social y represión armada, p. 358.

${ }^{99}$ J.A. JARA FUENTE, Doble representación y cruces de intereses, p. 301. 
antagonismos sociales internos y poner en manos de la monarquía la última palabra sobre todos aquellos conflictos y tensiones que se pudiesen suscitar. O dicho de forma vulgar, la monarquía encendió el fuego que puso a hervir, eso sí a cocción lenta, una caldera, que terminaría reventando a principios del siglo XVI, con el conflicto de las Germanías en el reino de Valencia, o en el caso castellano las Comunidades.

Parece más bien que el apoyo que Juan II ofrecía a Joan Rodríguez y a los ciudadanos menores de Orihuela o el que prestó a la Busca en Barcelona, no pretendía un sincero objetivo de promocionar a los grupos sociales y artesanales que ocupaban una posición inferior entre los grupos dirigentes urbanos, sino que más bien, se puede observar una calculada estrategia que pretendía debilitar a las poderosas oligarquías urbanas, alentando estas tensiones, reivindicaciones y conflictos, para de forma paulatina y gradual ir desmontando el sistema social urbano, en palabras de Barel ${ }^{100}$, que las oligarquías urbanas habían ido cimentando en los dos últimos siglos.

Fecha de recepción del artículo: mayo 2006

Fecha de aceptación y versión final: julio 2006.

${ }^{100}$ Y. BAREL, La ciudad medieval. Sistema social-Sistema urbano, Madrid, 1981. 